\title{
South African management literature over the past fifteen years: Content analysis of the three top South African management journals
}

\author{
E. Botha* \\ School of Management Studies, University of Cape Town, \\ Private Bag, Rondebosch 7701, Republic of South Africa \\ Elsamari.botha@uct.ac.za \\ N. Lilford \\ Department of Business Administration and Social Sciences, \\ Lulea University of Technology, Sweden \\ L. Pitt \\ Beedie School of Business, Simon Fraser University, Canada \\ Received January 2011
}

\begin{abstract}
This article analysed 15 years, from 1996 to 2010, of research published in the three leading South African business management journals. The three journals chosen were the South African Journal of Business Management, the South African Journal of Economic and Management Sciences and Management Dynamics. Content analysis was used to compare five broad themes in the journals: firstly the nature of authorship was examined, and then the most published as well as most prolific authors were identified. Thirdly, the most prominent universities and departments were identified whereafter the research themes and disciplines of the articles and authors were analysed. Lastly, various manuscript characteristics were investigated. This article provides a clear picture of the evolution of South African management literature over the past fifteen years.
\end{abstract}

*To whom all correspondence should be addressed.

\section{Introduction}

It is important for both business management researchers and those who evaluate them to have an up to date picture of the forum available for scholarly discourse. One means of assessing the nature of a field is to evaluate the communication system available to scholars in that discipline where books, journal articles and conference proceedings serve as primary communication channels for researchers (Holsapple, Johnson, Manakyan \& Tanner, 1993). Holsapple et al. (1993) further state that it is important to periodically take stock of channels available for communicating scholarly discourse and research.

It is essential that both academics and administrators be familiar with the differences among the forums available for publishing scholarly research (Holsapple et al., 1993). Consequently, publications in the three top South African management journals were analysed in order to obtain a broad picture of the current state of the art: the South African Journal of Business Management (SAJBM), the South African Journal of Economic and Management Sciences (SAJEMS) and Management Dynamics (MD). The purpose of this study was to gain a broad overview of the development of management research in South Africa over the past fifteen years.
Authors have periodically taken stock of the content of various journals (see Chandy \& Williams, 1994; Coudounaris, Kvasova, Leonidou, Pitt \& Nel, 2009; Inkpen \& Beamish, 1994; Phelan, Ferreira \& Salvador, 2002). Phelan et al. (2002) point out the benefits of such an analysis. First, it can act as a guide to potential authors with regards to changes in content, methodology and article length that can help direct their future publications. Second, the study of historical trends reveals new opportunities for the journals that have hitherto remained unexplored. In the case of the research presented here, it also assesses the impact that the editorial policies of these three journals have had on the shape and content of their articles over the past fifteen years.

Only academic articles published in the past fifteen years (1996-2010) were considered and as a result 1027 (500 SAJEMS, 231 Management Dynamics; 296 SAJBM) articles were analysed. This period was chosen as it represented the longest time-span for which we could obtain complete information on all articles in the three journals. To provide a historical perspective on the evolution of these management journals the sampling period was divided into three five year periods (1996-2000, 2001-2005, 2006-2010). Content analysis was used to compare five broad themes in 
the journals following the research design used by Coudounaris et al. (2009): first, the nature of authorship was examined, then the most published as well as the most prolific authors were identified. Third, the most prominent universities and departments were identified whereafter the research themes and disciplines of the articles and authors were analysed. Finally, the manuscript characteristics were investigated. This approach was used as we believe that it provides the most complete picture of the articles published in these three journals over the past fifteen years. The content analysis provided an in-depth view of what South African management research has been concerned with over the past fifteen years. The purpose of this paper is consequently to first, provide an analysis of the key characteristics of all the papers published in the top three South African management journals, and second to compare these three journals on the key characteristics of the articles published in them. Before the findings are discussed the editorial policy of each journal has been summarised.

\section{Journals' background}

SAJBM publishes articles that have real significance with respect to management practice. The content of the journal is comprised of two main categories namely managerial theory and management practice. Managerial theory focuses on the reporting of new methodological developments with a specific emphasis on the developments of the theory of management. Management practice focuses on the methodology in the application of scientific knowledge with a specific emphasis on practice. It therefore focuses on the conversion of management theory to practice, bearing in mind behavioural and economic realities.

SAJEMS is considered a leading publication for interdisciplinary research in economic and management sciences, with a special focus on the African continent. The main objective of this journal is to contribute to the understanding of African markets and the behaviour of economic agents operating in those markets, including consumers, firms and regulators.

MD publishes managerially-based scholarly articles in all business-related disciplines including strategic management, marketing, operations, human resources, organisational behaviour, consumer behaviour, research methods, information systems, customer satisfaction, business education and electronic commerce. Besides being multidisciplinary, the journal strives to be both national and international in scope.

These journals together provide an insight into the evolution of management literature in South Africa. The following sections first address the methodology used in this article, whereafter the main findings are discussed. The findings are presented in accordance with the five broad themes investigated in this article: the nature of authorship in the journals, the most published and most prolific authors, academic institution appearances, research themes and disciplines and lastly, manuscript characteristics.

\section{Methodology}

Content analysis was conducted by two separate analysts and all the data was checked by one of the researchers to ensure consistency of the coding. A third researcher verified a random number of articles to make sure that the articles were coded correctly.

The first broad theme that was analysed in each article was the nature of authorship including the number of authors, the number of institutions (i.e. the number of institutions represented by the authors of the paper), the number of countries (i.e. the number of countries represented by the authors of the paper), the type of author and the location of authors (i.e. the country represented by the author's affiliated institution). These were recorded as they appeared on the published article. As type of author, authors were classified as either academic or practitioner based on the institution that they affiliated with on the article. In some instances, authors listed more than one institution. In these cases, authors were classified as "other".

Morrison and Inkpen (1991) state that an important criterion used to evaluate university faculty and academic institutions is the publication records of each. The second broad theme investigated in this article was the most published and most prolific authors. The most prolific institutions and departments was the third broad theme investigated. Similar to other review article methodologies, both number of publications and adjusted number of publications were used to rank authors (see Coudounaris et al., 2009; Inkpen \& Beamish, 1994; Morrison \& Inkpen, 1991). Adjusted number of publications was calculated by weighting authors according to the number of authors per article. Therefore, if there was one author in the article, he or she was allocated a weighting of 1, two authors each were allocated half a weighting, three authors were allocated a weighting of a third and so on. The authors decided to use sheer number of publications as the primary ranking mechanism for the respective authors; however, when two authors published the same number of articles, their adjusted number of articles was used to determine their position.

The impact of the most prolific South African management researchers and the impact of the three journals were also assessed. Different approaches have been used to assess the impact of articles and journals including sending surveys to the top researchers in the field (for example DuBois \& Reed, 2000). However, technological advancement and the internet have made citation analysis the most reliable tool to assess the impact of authors' articles and journals. There is no "accepted" means of conducting a citation analysis (Holsapple et al., 1993). For this study, however, a popular citation analysis software tool was used, namely Harzing's (2010) Publish or Perish (see www.harzing.com). This software programme retrieves and analyses academic citations. It uses Google Scholar to obtain the raw citations, then analyses these and calculates a series of citation metrics. Publish or Perish metrics are considered to be fairly robust and insensitive to occasional errors (Harzing, 2010).

The H-index is a citation metric often used and is defined as an index to quantify an individual's scientific research 
output. It aims to measure the cumulative impact of a researcher's output by looking at the amount of citation his/her work has received. It therefore provides a combination of both quantity (number of papers) and quality (impact or number of citations). It is calculated as an index $h$ if $h$ of his/her $N p$ papers have at least $h$ citations each, and the other $(\mathrm{Np}-\mathrm{h})$ papers have no more than $h$ citations each (Harzing, 2005 in Harzing \& Van der Wal, 2008). Harzing and Van der Wal (2008) state that it is therefore preferable to measuring citations only as it corrects for "one hit wonders", i.e. authors that have published one or a limited number of highly cited papers but have not shown academic performance that has been sustained over a long period of time. The H-index can also be used as an indication of the impact of various journals. Hirsch's h-index is used by Publish and Perish and is considered to provide a more accurate and comprehensive measure of journal impact than the ISI Journal Impact Factor (Harzing \& Van der Wal, 2008). One limitation that should be mentioned when using citation analysis is that this method is biased towards older articles that have had more time to accumulate multiple citations (Morrison \& Inkpen, 1991).

The H-index of a journal can be regarded as an indication of the quality of a journal. Journal quality has often been taken into consideration when evaluating publication track records even though perceived journal quality can vary over time (Morrison \& Inkpen, 1991). In December 2010, the South African Journal of Business Management had an H-index of 13. The South African Journal of Economic and Management Sciences had an $\mathrm{H}$-index of 9. Management Dynamics had an $\mathrm{H}$-index of 7. In order to compare these figures we can take a look at the $\mathrm{H}$ scores of the top management journals in the world, rated according to the highest H scores: Administrative Science Quarterly (124) and Academy of Management Review (264) (Harzing \& Van der Wal, 2008).

In all instances, institutions were credited as they were referenced in the article (Morrison \& Inkpen, 1991). The academic institution landscape in South Africa has undergone many changes in the past fifteen years. Most notably, many of the institutions have merged. This article reflects the current academic landscape. Therefore, if an article was published by, for example, an author from the University of Port Elizabeth, it was reflected as an article from Nelson Mandela Metropolitan University, because the latter is now the name of the former, plus a number of other institutions that were merged.

The fourth theme of the article was to investigate trends in the research themes and disciplines of articles over the past fifteen years. The articles were classified by primary discipline area where the disciplines used were adapted from those used in Chandy and Williams (1994), Coudounaris et al. (2009) and Inkpen and Beamish (1994).

Finally, manuscript characteristics were investigated, including the proportion of empirical versus non-empirical research articles in each of the journals, the distribution of qualitative and quantitative articles as well as the specific methodologies employed. As part of the manuscript's characteristics the page length of articles was analysed.
Paired sample t-tests were used to assess whether any of the changes across all three journals and across the three five year periods were significant.

\section{Results and discussion}

In this section of the paper, the results are presented and discussed.

\section{Nature of authorship}

The average number of authors per paper differed slightly for each journal: articles from SAJBM had 2,18 authors on average, compared to 1,83 in SAJEMS and 2,09 in MD. Table 1 summarises the author characteristics of all the articles over all three journals.

There has been a decline in the number of single authored articles, while the number of articles with three or four authors has been steadily increasing over the past fifteen years. This reflects findings in international journals (Chandy \& Williams, 1994; Coudounaris et al., 2009) where the trend is clearly away from single authored articles toward collaborative research. Inkpen and Beamish (1994) similarly found that the proportion of single authored articles in the Academy of Management Journal, the Academy of Management Review and Administrative Science Quarterly dropped from 82 per cent in the 1960s to 40 per cent in the early nineties.

There was a significant increase, at a five per cent level of significance, in the number of authors per article from the 2001-2005 time period to the 2006-2010 time period. However, the increase from 1996-2000 to 2001-2005 was not significant. This could be an indication that even though South African researchers regained access to international networks at the fall of Apartheid in 1994, it took authors a decade to start networking internationally. This finding was concurred when considering the number of international collaborations in the journals. In the past fifteen years, less than ten per cent of articles were generated from international collaborations. This is below international standards. In comparison, Coudounaris et al. (2009) found that, in reviewing Management International Review, more than 20 per cent of articles had authors from different countries.

The number of collaborations across institutions has increased during the past fifteen years, from 19 per cent in 1996-2000 to 21 per cent in 2005-2010. A significant increase was observed in the last decade where collaborations between three or more institutions increased from 1.7 per cent to five per cent during the past fifteen years. In international management literature, on the other hand, Coudounaris et al. (2009) found that only 51 per cent of articles were by scholars from the same institution, 36 per cent from authors from two institutions and 13 per cent by authors belonging to three or more institutions. 
Table 1: Nature of authorship

\begin{tabular}{|c|c|c|c|c|c|c|c|}
\hline \multirow{2}{*}{$\begin{array}{l}\text { Author } \\
\text { Characteristics }\end{array}$} & \multirow{2}{*}{$\begin{array}{c}\text { Total } \\
\text { SAJBM } \\
(\mathbf{n}=296) \%\end{array}$} & \multirow{2}{*}{$\begin{array}{c}\text { Total SAJEMS } \\
(\mathbf{n}=\mathbf{5 0 0}) \%\end{array}$} & \multirow{2}{*}{$\begin{array}{l}\text { Total MD } \\
(\mathbf{n}=\mathbf{2 3 1}) \%\end{array}$} & \multirow{2}{*}{$\begin{array}{c}\text { Overall Average } \\
\quad(n=1027) \%\end{array}$} & \multicolumn{3}{|c|}{ Time Period(Comparison of all articles) } \\
\hline & & & & & $\begin{array}{c}1996-2000 \\
n=318\end{array}$ & $\begin{array}{c}2001-2005 \\
n=378\end{array}$ & $\begin{array}{c}2006-2010 \\
n=231\end{array}$ \\
\hline \multicolumn{8}{|c|}{ Number of Authors } \\
\hline One & $23 \%$ & $41 \%$ & $27,3 \%$ & $32,5 \%$ & $38,4 \%$ & $31,5 \%$ & $28,2 \%$ \\
\hline Two & $46 \%$ & $41 \%$ & $45,5 \%$ & $43,4 \%$ & $42,5 \%$ & $45,2 \%$ & $42,4 \%$ \\
\hline Three & $24 \%$ & $15 \%$ & $19 \%$ & $18,7 \%$ & $17 \%$ & $18 \%$ & $21,2 \%$ \\
\hline Four & $5 \%$ & $2 \%$ & $7,8 \%$ & $4,1 \%$ & $1,3 \%$ & $4,8 \%$ & $6,1 \%$ \\
\hline More than four & $2 \%$ & $1 \%$ & $0,4 \%$ & $1,3 \%$ & $0,8 \%$ & $0,5 \%$ & $2,1 \%$ \\
\hline \multicolumn{8}{|c|}{ Number of Institutions } \\
\hline One & $79 \%$ & $79 \%$ & $72,3 \%$ & $76,4 \%$ & $79,5 \%$ & $78,6 \%$ & $73,6 \%$ \\
\hline Two & $19 \%$ & $18 \%$ & $26,8 \%$ & $20 \%$ & $18,8 \%$ & $20,4 \%$ & $21,2 \%$ \\
\hline Three or more & $2 \%$ & $3 \%$ & $0,9 \%$ & $3,6 \%$ & $1,7 \%$ & $1 \%$ & $5,2 \%$ \\
\hline \multicolumn{8}{|c|}{ Number of Countries } \\
\hline One & $92 \%$ & $93 \%$ & $93,3 \%$ & $92,8 \%$ & $92,9 \%$ & $94,7 \%$ & $90,3 \%$ \\
\hline Two & $8 \%$ & $6 \%$ & $6,7 \%$ & $6,7 \%$ & $6,8 \%$ & $5,3 \%$ & $8,5 \%$ \\
\hline Three & $0 \%$ & $1 \%$ & $0 \%$ & $0,5 \%$ & $0,3 \%$ & $0 \%$ & $1,2 \%$ \\
\hline \multicolumn{8}{|c|}{ Type of Author } \\
\hline Academic & $96 \%$ & $90,1 \%$ & $95,8 \%$ & $94 \%$ & $96,2 \%$ & $91,8 \%$ & $90,2 \%$ \\
\hline Practitioner & $4 \%$ & $8,1 \%$ & $4,2 \%$ & $5,4 \%$ & $3,8 \%$ & $5,5 \%$ & $7,3 \%$ \\
\hline Other & $0 \%$ & $1,8 \%$ & & $1,8 \%$ & & $2,7 \%$ & $2,5 \%$ \\
\hline \multicolumn{8}{|c|}{ Location of authors } \\
\hline South Africa & $93,1 \%$ & $86,6 \%$ & $94,3 \%$ & $91,3 \%$ & $92,7 \%$ & $89,3 \%$ & $87,7 \%$ \\
\hline Rest of Africa & $1,6 \%$ & $4,6 \%$ & $0,8 \%$ & $2,3 \%$ & $1,4 \%$ & $4,3 \%$ & $2,7 \%$ \\
\hline Americas & $1,7 \%$ & $3,1 \%$ & $1,7 \%$ & $2,2 \%$ & $2,1 \%$ & $3,7 \%$ & $2,5 \%$ \\
\hline Europe & $1,7 \%$ & $4,1 \%$ & $1,3 \%$ & $2,4 \%$ & $1,9 \%$ & $1,9 \%$ & $4,3 \%$ \\
\hline Asia & $0,2 \%$ & $0,2 \%$ & $0,2 \%$ & $0,2 \%$ & $0,2 \%$ & $0,1 \%$ & $0,3 \%$ \\
\hline $\begin{array}{l}\text { Australia and New } \\
\text { Zealand }\end{array}$ & $0,8 \%$ & $1,1 \%$ & $0,6 \%$ & $0,8 \%$ & $1,6 \%$ & $0,7 \%$ & $0,7 \%$ \\
\hline Rest of world & $0,9 \%$ & $0,3 \%$ & $1,1 \%$ & $0,8 \%$ & $0,1 \%$ & $0 \%$ & $1,8 \%$ \\
\hline
\end{tabular}

When considering each of the three journals separately, it can be seen that the majority of articles in SAJEMS were single authored (41 per cent), as opposed to only 23 per cent in SAJBM and 27 per cent in MD. The single article with the most authors was a SAJBM article with nine authors, however, these articles formed outliers in the dataset and usually came in the form of report type articles on large industry or government projects. Management Dynamics was the journal with the most institution collaborations where in 28 per cent of articles authors were from two or more institutions. This was opposed to the approximate 20 per cent average of the other two journals. However, most of these collaborations were within national borders as all three journals have approximately 93 per cent of their authors originating from one country.

The majority of authors were from academic institutions, however, a significant increase in the number of papers published by practitioners was observed. SAJEMS was the journal that had the most practitioner articles, with 8,1 per cent of articles authors outside of university environments. When looking at the practitioners who published in the journals, there were 79 (approximately 4 per cent of all publications) from private institutions and 52 (approximately 2,5 per cent of all publications) that were affiliated with government. In SAJEMS the number of authors from private institutions as opposed to government was relatively equal.

There has been a steady increase in the number of international authors publishing in these three South African journals. The percentage of South African authors decreased from 93 per cent of all authors in 1996-2000, to 88 per cent in the past five years. Initially, publications from America and the rest of Africa increased, however, in the past five years, these have again tapered down and publications from authors in Europe have in turn increased. Consistent with their editorial policy, SAJEMS is the journal with the highest percentage of authors from outside South Africa, particularly Africa (almost 5 per cent). SAJEMS is also the 
journal with the largest number of authors from America, Europe, Australia and New Zealand.

Researchers from all over Africa have published in the three journals including Sierra Leone (1), Nigeria (25), Namibia (2), Botswana (6), Ghana (3), Lesotho (2), Cameroon (1) and Malawi (1). The majority, fifty-six per cent, of authors were from Nigeria, followed by 13 per cent from Namibia.

\section{Most published and most prolific authors}

Overall, 417 authors have published in SAJBM, 642 have published in SAJEMS and 295 have published in MD. Table 2 lists the authors that have appeared most in each of the three journals over the past fifteen years.

Table 2: Authors that have published most often in SAJBM, SAJEMS and MD

\begin{tabular}{l|l|l|l|l|l|l|l}
\hline Most articles in SAJBM & No. & $\begin{array}{l}\text { Adj. } \\
\text { No }\end{array}$ & Most articles in SAJEMS & No. & $\begin{array}{l}\text { Adj. } \\
\text { No }\end{array}$ & $\begin{array}{l}\text { Most articles in MD } \\
\text { No. }\end{array}$ \\
\hline Boshoff, C & 25 & 13.25 & Rothmann, S & 9 & 4,83 & Boshoff, C \\
\hline Smit, EvdM & 23 & 8.58 & Schoeman, NJ & 9 & 4,03 & Rothman, S \\
\hline Abratt, R & 12 & 4.17 & Boshoff, AB & 9 & 3,67 & Terblanche, NS & 21 \\
\hline Terblanche, NS & 11 & 6.83 & Ortmann, GF & 8 & 3,17 & Venter, DJL \\
\hline Hamman, WD & 11 & 4.20 & Blignaut, JN & 8 & 3,10 & Venter, E \\
\hline Oosthuizen, H & 10 & 7.5 & Terblanche, NS & 8 & 3,83 & Engelbrecht, AS & 8,33 \\
\hline De Coning, TJ & 7 & 2.33 & Du Toit, CB & 7 & 4 & Erasmus, PD & 3,5 \\
\hline Thomas, A & 6 & 3 & Boshoff, C & 7 & 3,33 & Rousseau, GG & 7 \\
\hline Bendixen, M & 6 & 2.17 & Vermeulen, LP & 6 & 2,5 & Bloom, JZ & 3,42 \\
\hline Firer, C & 5 & 2.12 & Mahadea, D & 5 & 3,83 & Smit, EvdM & 3,33 \\
\hline
\end{tabular}

Christo Boshoff was the most published author in both SAJBM and MD and eighth most published in SAJEMS. In SAJBM he was followed by Eon Smit and Russell Abratt when sheer number of articles was considered. However, with the adjusted article count, $\mathrm{H}$ Oosthuizen was the third ranked author in the journal as most of his 10 articles were either single authored or had two authors at the most. Similarly, Nic Terblanche also had a higher rating when the adjusted publication count was considered for both SAJBM and MD. It should also be mentioned that Nic Terblanche and Christo Boshoff were the only authors that appeared in all three journals' top ten authors list. Both these authors are currently at the University of Stellenbosch's Department of Business Management.

The author that has published the most articles in SAJEMS over the past fifteen years was Sebastiaan Rothmann from North-West University, Potchefstroom. He was also the second most published author in Management Dynamics. He was followed by NJ Schoeman and AB Boshoff. When considering the adjusted publication count, the order of authors differs from the frequency count in that $\mathrm{CB}$ du Toit would be ranked third in SAJEMS. One author worth mentioning in this journal was R Gupta, even though his adjusted number of publications was 3,5, his five papers just fell short of D Mahadea's five papers and 3,83 adjusted publication count.

Table 3 looked at which author published the most articles when all three journals were considered. Harzing's H-index was also given as an indication of the impact of the articles that each author has written. The H-index, however, considers not only the journals in question, but uses all citations picked up by the Publish or Perish software. This provides a bigger picture of the impact that these authors have had both nationally and internationally.

\section{Table 3: Most prolific and most published author}

\begin{tabular}{|c|c|c|c|c|}
\hline Name of Author & Current affiliation & $\begin{array}{c}\text { Total number of publications in } \\
\text { SAJBM, SAJEMS and MD }\end{array}$ & $\begin{array}{c}\text { Adjusted number of } \\
\text { publications }\end{array}$ & Harzing's H-index \\
\hline Boshoff, C & Stellenbosch University & 54 & 26,83 & 15 \\
\hline Smit, EvdM & Stellenbosch University & 33 & 12,58 & 3 \\
\hline Terblanche, NS & Stellenbosch University & 31 & 18,99 & 5 \\
\hline Rothmann, S & North-West University & 26 & 13,74 & 5 \\
\hline Abratt, R & University of Witwatersrand & 17 & 5,17 & 20 \\
\hline Venter, DJL & Nelson Mandela Metropolitan University & 15 & 6,58 & 2 \\
\hline Hamman, WD & Stellenbosch University & 14 & 5,03 & 2 \\
\hline Boshoff, AB & University of Pretoria & 12 & 4,75 & 5 \\
\hline Oosthuizen, $\mathrm{H}$ & Stellenbosch University & 10 & 7,5 & 2 \\
\hline Rousseau, GG & Nelson Mandela Metropolitan University & 11 & 5,17 & 2 \\
\hline
\end{tabular}


Christo Boshoff was the business management author with the most publications. His most cited article, according to Harzing's Publish or Perish, was the article concerned with developing a better measure for market orientation in the European Journal of Marketing (Gray, Matear, Boshoff \& Matheson, 1998). He was followed, in terms of number of publications, by Eon Smit and Nic Terblanche. Russell Abratt, however, was the most cited author from the list of authors.

The most influential article in each journal was also determined using Harzing's Publish or Perish. The most cited article in SAJBM was an article that provided a measurement instrument for organisational culture (Van der Post, De Coning \& Smit, 1997). Basson and Rothman's (2002) article on sense of coherence, coping and burnout of pharmacists was the most cited article in SAJEMS. In
Management Dynamics, the article by Ellis and Steyn (2003) regarding practical significance versus statistical significance (or p-values) was most cited.

\section{Academic institution appearances}

The following table provides a summary of the academic institutions with the most appearances in the three journals over the past fifteen years. It should be noted, however, that these figures were not adjusted for the size of institution or department and sheer numbers were the only consideration. Also, faculty mobility can dramatically influence institutional standings over a fifteen year period (Inkpen \& Beamish, 1994; Morrison \& Inkpen, 1991).

Table 4: Top five academic institution appearances

\begin{tabular}{|c|c|c|c|c|c|}
\hline \multicolumn{6}{|c|}{ All three journals } \\
\hline \multicolumn{2}{|l|}{$1996-2000(n=318)$} & \multicolumn{2}{|l|}{$2001-2005(n=378)$} & \multicolumn{2}{|c|}{$2006-2010(n=231)$} \\
\hline Institution & No. & Institution & No. & Institution & No. \\
\hline University of Pretoria & 105 & University of Stellenbosch & 135 & University of Stellenbosch & 120 \\
\hline University of Stellenbosch & 95 & University of Pretoria & 123 & University of Pretoria & 117 \\
\hline University of Witwatersrand & 64 & North-West University & 81 & University of Cape Town & 74 \\
\hline University of Kwazulu-Natal & 49 & University of Cape Town & 75 & University of Witwatersrand & 56 \\
\hline $\begin{array}{l}\text { North-West University and Nelson } \\
\text { Mandela Metropolitan University }\end{array}$ & 43 & $\begin{array}{lll}\text { Nelson } & \text { Mandela } & \text { Metropolitan } \\
\text { University }\end{array}$ & 66 & North-West University & 52 \\
\hline
\end{tabular}

The two competitors for first place with regards to the most published articles in the three management journals are the University of Pretoria and Stellenbosch University. The difficulty of maintaining institutional leadership is compounded by the departure of both key faculty and doctoral students (Inkpen \& Beamish, 1994), however, Stellenbosch University has been able to remain at the top. This position was no doubt heavily affected by the number of influential management researchers affiliated with the institution (see previous section).

All authors' stated departments were also recorded. For all three time periods (1996-2000, 2001-2005 and 2006-2010) the majority of authors were from general management departments. Management departments accounted for approximately 50 per cent of all publications in these three journals. Thereafter, with approximately 20 per cent of the publications, were scholars from Economics departments. A steady increase in publications from Finance and Accounting departments could be seen with an increase from 4,7 per cent in 1996-2000, to 5.6 per cent in 2001-2005 and 8,7 per cent in 2006-2010. An increase in Information Systems departments was also observed, from 1,3 per cent in 1996-2000 to 3.2 per cent and recently 5,3 per cent. Similarly, a steady decrease in publications from HR and Organisational Psychology departments was observed: from 9,2 per cent of publications in 1996-2000, to 8,7 per cent in 2001-2005 and 5,3 per cent in 2006-2010. Publications from other departments remained relatively stable over the past fifteen years.

\section{Research themes and disciplines}

Table 5 summarizes the distribution of published disciplines over the past 15 years.

Table 5: Discipline of all management articles over the last 15 years

\begin{tabular}{l|c|c|c|c}
\hline Discipline & $\begin{array}{c}\mathbf{1 9 9 6 -} \\
\mathbf{2 0 0 0} \\
\mathbf{n = 3 1 8}\end{array}$ & $\begin{array}{c}\mathbf{2 0 0 1 -} \\
\mathbf{2 0 0 5} \\
\mathbf{n = 3 7 8}\end{array}$ & $\begin{array}{c}\mathbf{2 0 0 6 -} \mathbf{2 0 1 0} \\
\mathbf{n = 3 3 0}\end{array}$ & $\begin{array}{c}\text { Overall } \\
\text { total } \\
\mathbf{n = 1 0 2 7}\end{array}$ \\
\hline Finance and Accounting & $15,4 \%$ & $11,9 \%$ & $14,8 \%$ & \\
\hline Economics & $24,8 \%$ & $22,5 \%$ & $22,4 \%$ & \\
\hline Marketing & $16,7 \%$ & $15,1 \%$ & $17,9 \%$ & \\
\hline $\begin{array}{l}\text { HR and Organisational } \\
\text { Psychology }\end{array}$ & $13,2 \%$ & $13,3 \%$ & $11,8 \%$ & \\
\hline $\begin{array}{l}\text { Management and } \\
\text { Strategy }\end{array}$ & $23 \%$ & $28,4 \%$ & $27 \%$ & \\
\hline Law & $0,3 \%$ & $0,3 \%$ & $0,3 \%$ & \\
\hline Statistics & $0,9 \%$ & $1,1 \%$ & $0,6 \%$ & \\
\hline $\begin{array}{l}\text { Information and } \\
\text { Knowledge Management }\end{array}$ & $0,3 \%$ & $1,3 \%$ & $2,1 \%$ & \\
\hline Other Areas & $4,1 \%$ & $6,1 \%$ & $3,0 \%$ & \\
\hline
\end{tabular}

Table 5 shows that the South African business knowledge system is deeply embedded in the management, financial management, economics and marketing disciplines as they consistently represented more than eighty per cent of the articles published in these three journals. Chandy and Williams (1994) also found, in the Journal of International Business Studies, that management, economics and marketing represented more than half of the citations that 
they measured. The contribution of most of the disciplines remained relatively equal in all three time periods. There is a growing number of authors that specialize in Information and Knowledge Management from 0,3 per cent in 19962000 to 2.1 per cent in 2006-2010.

The contribution from each discipline differs greatly when considering the three journals separately (see Table 6). Forty three per cent of articles in SAJEMS, for example, were concerned with Economics related topics as opposed to only 4 per cent in SAJBM and 6 per cent in MD. This however, could be explained by the editorial policy and focus of the journal.

Table 6: Research areas of articles published in all three journals over all fifteen years

\begin{tabular}{l|c|c|c}
\hline Discipline & $\begin{array}{c}\text { SAJBM } \\
\mathbf{n = 2 9 6}\end{array}$ & $\begin{array}{c}\text { SAJEMS } \\
\mathbf{n = 5 0 0}\end{array}$ & $\begin{array}{c}\text { MD } \\
\mathbf{n = 2 3 1}\end{array}$ \\
\hline Finance and Accounting & $16,3 \%$ & $12,4 \%$ & $14,3 \%$ \\
\hline Economics & $4,1 \%$ & $42,5 \%$ & $6,1 \%$ \\
\hline Marketing & $21,7 \%$ & $10,8 \%$ & $23,8 \%$ \\
\hline $\begin{array}{l}\text { HR and Organisational } \\
\text { Psychology }\end{array}$ & $12,9 \%$ & $9,8 \%$ & $19 \%$ \\
\hline $\begin{array}{l}\text { Management and Strategy } \\
\text { Law }\end{array}$ & $36,3 \%$ & $18,6 \%$ & $29,9 \%$ \\
\hline Statistics & $0,3 \%$ & $0,2 \%$ & $0,4 \%$ \\
\hline $\begin{array}{l}\text { Information and Knowledge } \\
\text { Management }\end{array}$ & $2,7 \%$ & $0,6 \%$ & $0,9 \%$ \\
\hline Other Areas & $4,4 \%$ & $4,8 \%$ & $3,9 \%$ \\
\hline
\end{tabular}

In both SAJBM and MD, the majority of articles were concerned with management and/or strategy related topics (36 per cent and 30 per cent respectively), with marketingrelated articles as the second most published topic (22 per cent and 24 per cent respectively). In SAJBM however, the third most published topic was finance and accounting where HR related articles were third in line in MD. Information and Knowledge Management articles were also more prominent in SAJBM than in the other two journals.

Even though SAJEMS is an economic and management sciences related journal, articles specialising in economics (43 per cent) more than doubled those concerned with management or strategy (19 per cent). The third most popular topic in SAJEMS was finance and accounting whereafter marketing related articles followed. This may be an indication not only of the type of articles that get accepted in each journal, but also the perception in academia with regards to which discipline should publish in which journal. The following section provides insight into the methodologies that were attracted by these journals.

\section{Manuscript characteristics}

Over all three journals, a total of 77 per cent of all the publications featured empirical research. Empirical research increased from 73 per cent in 1996-2000, to 74,3 per cent in 2001-2005 and 84,5 per cent in 2006-2010 (significant at a five per cent level of significance) as opposed to non- empirical research that decreased to 15,5 per cent of all publications in the past five years. In SAJBM 81 per cent of all articles had conducted empirical research and a similar amount of empirical research, 84 per cent, was observed in MD. However, in SAJEMS only 72 per cent of articles had conducted empirical research. The rest of the articles were concerned with the development of theory or literature reviews. Phelan et al. (2002), in their review of the Strategic Management Journal (SMJ), found that the number of empirical papers increased from around 50 per cent in the early years of SMJ to approximately 70 per cent of all articles in 1999. Table 7 investigates the methodologies that these empirical studies favoured.

Table 7: Research design and methodology of articles over all three journals

\begin{tabular}{|c|c|c|c|c|c|}
\hline $\begin{array}{l}\text { Research } \\
\text { Design }\end{array}$ & $\begin{array}{l}\text { Research } \\
\text { Methodology }\end{array}$ & $\begin{array}{c}1996- \\
2000 \\
n= \\
318\end{array}$ & $\begin{array}{c}2001- \\
2005 \\
n= \\
378\end{array}$ & $\begin{array}{c}2006- \\
2010 \\
n= \\
330\end{array}$ & $\begin{array}{c}\text { Overall } \\
\text { total } \\
\mathbf{n}= \\
1027 \\
\end{array}$ \\
\hline $\begin{array}{l}\text { Theory } \\
\text { Development }\end{array}$ & $\begin{array}{l}\text { Formal Theory } \\
\text { / Literature } \\
\text { Review }\end{array}$ & $\begin{array}{l}26,7 \\
\%\end{array}$ & $\begin{array}{l}25,1 \\
\%\end{array}$ & $\begin{array}{l}15,5 \\
\%\end{array}$ & $22,5 \%$ \\
\hline \multirow[t]{4}{*}{ Quantitative } & Surveys & $\begin{array}{l}39,5 \\
\%\end{array}$ & $\begin{array}{l}43,1 \\
\%\end{array}$ & $\begin{array}{l}40,6 \\
\%\end{array}$ & $41,2 \%$ \\
\hline & $\begin{array}{l}\text { Experimental } \\
\text { design }\end{array}$ & $1 \%$ & $1,3 \%$ & $2,4 \%$ & $1,6 \%$ \\
\hline & $\begin{array}{l}\text { Observation } \\
\text { (Quantitative) }\end{array}$ & $0 \%$ & $0 \%$ & $0,6 \%$ & $0,2 \%$ \\
\hline & $\begin{array}{l}\text { Analysis of } \\
\text { existing data }\end{array}$ & $\begin{array}{l}22,2 \\
\%\end{array}$ & $\begin{array}{l}19,8 \\
\%\end{array}$ & $\begin{array}{l}20,9 \\
\%\end{array}$ & $20,9 \%$ \\
\hline \multirow[t]{5}{*}{ Qualitative } & Interviews & $2,9 \%$ & $2,1 \%$ & $5,5 \%$ & $3,4 \%$ \\
\hline & Focus groups & $0,3 \%$ & $0,3 \%$ & $1,2 \%$ & $0,6 \%$ \\
\hline & Observation & $2,6 \%$ & $0,8 \%$ & $1,8 \%$ & $1,7 \%$ \\
\hline & $\begin{array}{l}\text { Content } \\
\text { Analysis }\end{array}$ & $1,6 \%$ & $1,6 \%$ & $3 \%$ & $2,1 \%$ \\
\hline & Case Studies & $1,3 \%$ & $3,4 \%$ & $5,2 \%$ & $3,3 \%$ \\
\hline Other & Triangulation & $1,9 \%$ & $2,4 \%$ & $3,3 \%$ & $2,6 \%$ \\
\hline
\end{tabular}

During 2001-2005 there was an increase in the number of quantitative as opposed to qualitative papers. In 1996-2000, 81 per cent of articles were quantitative. This increased to 85 per cent in 2001-2005 and decreased to 79 per cent in 2006-2010. This last decline could be attributed to a number of factors including the advancement of qualitative research technology like How Sociable? and Google Analytics, and the abundance of qualitative data (for example blogs and web pages) on the internet. Consequently, qualitative data is now more readily available as well as in abundance.

Over all three time periods the majority, approximately 40 per cent of all studies, used survey research design. Even though the use of other quantitative methodologies remained relatively stable over the past fifteen years, there has been an increase in the use experimental design. Applying this methodology to management problems has become increasingly popular over the past decade. The increased preference of quantitative methodologies was accompanied by a decrease in formal theory and literature review studies from 27 per cent in 1996-2000 to approximately 16 per cent in 2006-2010. Of the quantitative research methods, case study research has marginally increased over the past fifteen years from only 1,3 per cent of articles in 1996-2000 to 5,2 per cent in 2006-2010. So too has the use of interviews, focus groups and content analysis, where interviews was the 
most preferred qualitative research method in the past five years.

Certain authors may prefer specific journals because of the methodologies favoured (or attracted) by those journals (Morrison \& Inkpen, 1991). Table 8 provides an indication of the methodology attracted by each journal.

Table 8: Research methodology of articles in each journal over all fifteen years

\begin{tabular}{l|l|c|c|c}
\hline $\begin{array}{l}\text { Research } \\
\text { Design }\end{array}$ & $\begin{array}{l}\text { Research } \\
\text { Methodology }\end{array}$ & $\begin{array}{c}\text { SAJBM } \\
(\mathbf{n = 2 9 6})\end{array}$ & $\begin{array}{c}\text { SAJEMS } \\
(\mathbf{n = 5 0 0})\end{array}$ & $\begin{array}{c}\text { MD } \\
(\mathbf{n = 2 3 1})\end{array}$ \\
\hline $\begin{array}{l}\text { Theory } \\
\text { Development }\end{array}$ & $\begin{array}{l}\text { Formal Theory / } \\
\text { Literature } \\
\text { Review }\end{array}$ & $18,9 \%$ & $27,7 \%$ & $15,6 \%$ \\
\hline \multirow{2}{*}{ Quantitative } & Surveys & $44,3 \%$ & $33,7 \%$ & $54 \%$ \\
\cline { 2 - 5 } & $\begin{array}{l}\text { Experimental } \\
\text { design }\end{array}$ & $1,7 \%$ & $1,4 \%$ & $1,8 \%$ \\
\cline { 2 - 5 } & $\begin{array}{l}\text { Observation } \\
\text { (Quantitative) }\end{array}$ & $0 \%$ & $0,4 \%$ & $0 \%$ \\
\cline { 2 - 5 } & $\begin{array}{l}\text { Analysis of } \\
\text { existing data }\end{array}$ & $15,2 \%$ & $28,5 \%$ & $11,6 \%$ \\
\hline \multirow{7}{*}{ Qualitative } & Interviews & $8,8 \%$ & $1,4 \%$ & $0,9 \%$ \\
\cline { 2 - 5 } & Focus groups & $1 \%$ & $0,4 \%$ & $0,4 \%$ \\
\cline { 2 - 5 } & Observation & $2,4 \%$ & $0 \%$ & $4,5 \%$ \\
\cline { 2 - 5 } & $\begin{array}{l}\text { Content } \\
\text { Analysis }\end{array}$ & $1,4 \%$ & $1,6 \%$ & $4,0 \%$ \\
\cline { 2 - 5 } & Case Studies & $2,7 \%$ & $4 \%$ & $2,7 \%$ \\
\hline Other & Triangulation & $3,7 \%$ & $1 \%$ & $4,5 \%$ \\
\hline
\end{tabular}

Overall, SAJEMS has published the most formal theory articles (almost 28 per cent). With its focus on Economics, SAJEMS also publishes the largest percentage of articles analysing existing data with 29 per cent of articles using this methodology as opposed to only 0,7 per cent in SAJBM and 11,6 per cent in MD. Analysis of existing data includes articles using for example economic data or stock exchange data or company financial reports. More than 50 per cent of articles in MD used survey research to test their research questions, whereafter formal theory / literature studies $(15,6$ per cent) and analysis of existing data (11,6 per cent) followed. Survey research was also very popular in SAJBM. The three journals attracted different qualitative methodologies where most qualitative research in SAJBM used interviews. SAJEMS, on the other hand, preferred case study analysis and MD preferred observation and content analysis.

Finally, this study investigated whether there has been any significant change in the average page length of articles over the past fifteen years. On average, articles in SAJBM were 9,55 pages long, 15,55 long in SAJEMS and 16,42 pages long in MD. Table 9 provides the average page length of articles in each journal for the past fifteen years where Figure 1 visually maps these averages to see if any trends appeared. In Figure 1 the X-axis represents the fifteen years and the $y$-axis represents the average page lengths of each of the journals where series 1 represents SAJBM, series 2 is SAJEMS and series 3 is the average page length of MD articles.

In SAJBM, page lengths of articles hovered around 10 pages per article for all fifteen years. In SAJEMS, page lengths remained above 15 pages from 1996 until 2004 with the exception of 1997. MD on the other hand, had significantly longer articles than the other two journals for the first six years of review peaking at an average page length of 26 pages in 2000 whereafter MD articles averaged out to similar page lengths to the other two journals.

Table 9: Average page length of articles in all three journals over the past fifteen years

\begin{tabular}{l|l|l|l|l|l|l|l|l|l|l|l|l|l|l|l|l|l}
\hline Journal & $\mathbf{9 6}$ & $\mathbf{9 7}$ & $\mathbf{9 8}$ & $\mathbf{9 9}$ & $\mathbf{0 0}$ & $\mathbf{0 1}$ & $\mathbf{0 2}$ & $\mathbf{0 3}$ & $\mathbf{0 4}$ & $\mathbf{0 5}$ & $\mathbf{0 6}$ & $\mathbf{0 7}$ & $\mathbf{0 8}$ & $\mathbf{0 9}$ & $\mathbf{1 0}$ \\
\hline SAJBM & 8 & 9 & 10 & 9 & 8 & 10 & 9 & 9 & 9 & 11 & 10 & 10 & 9 & 11 & 10 \\
\hline SAJEMS & 16 & 11 & 16 & 16 & 16 & 17 & 20 & 19 & 15 & 13 & 14 & 14 & 16 & 15 & 16 \\
\hline MD & 19 & 20 & 21 & 21 & 26 & 23 & 10 & 10 & 12 & 14 & 11 & 13 & 14 & 13 & 14 \\
\hline
\end{tabular}

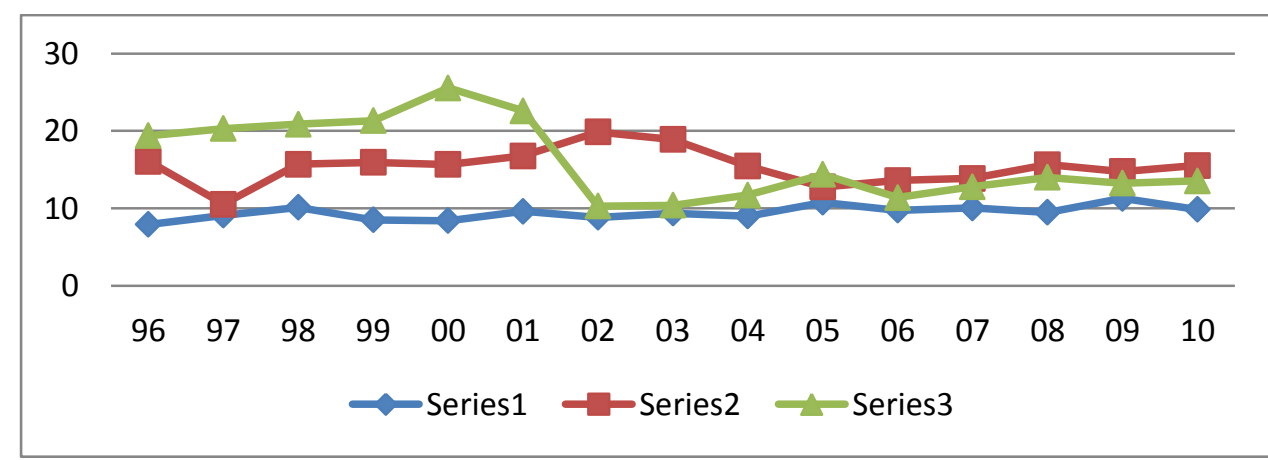

Figure 1: Page lengths of all three journals over the past fifteen years

There was disparity between journals with regard to the average page length of papers. SAJBM consistently published shorter articles than the other two journals. In both the 1996-2000 and 2006-2010 time periods, there was a significant difference between the page lengths of the three journals. This could be attributed to the different disciplines that are attracted by each journal where financial management, accounting and economics articles are typically shorter. Page length was significantly related to the research methodologies of the articles for both the 19962000 and 2006-2010 time periods. 


\section{Conclusion}

This systematic review of South African business and management journals plays a critical role in benchmarking these journals against international and other highly rated journals. The authors and institutions ranked in this paper have all made significant contributions to South African management literature over the past 15 years. The contribution of individual authors to the South African business management body of knowledge is not recognised often enough, and consequently the top publishing authors in the three journals were identified. These researchers have contributed to business management literature both nationally and internationally and the names provided in both Table 3 (top researchers) and Table 4 (top institutions) can assist future students in their decision regarding where to do both undergraduate and post-graduate research.

To the extent that these three journals reflect the evolution of management literature in South Africa, the analysis of the past fifteen years has raised some interesting questions about future directions. The reasons why, for example, research disciplines and preferences for certain methodologies have evolved the way they have and whether or not these are healthy trends was not considered. Inkpen and Beamish (1994) state that questions like these are important and require broad-based discussion.

Morrison and Inkpen (1991) state that while some authors publish in a wide variety of journals, others focus on specific outlets because of a special interest in the journal's target audience or because of their skill in using a methodology attracted by the journal. This article attempted to provide a full picture of both the methodologies and audiences drawn or attracted by SAJBM, SAJEMS and MD. This paper found that in general, there has been a decrease in the number of formal theory and literature review articles in all three journals while the use of quantitative methodologies (especially experimental design) has increased. Overall, SAJEMS has published the most formal theory articles and with its Economics focus, SAJEMS has published the most articles that focused on the analysis of existing data. The majority of research in MD utilizes survey research designs. It was also found that the three journals attracted different qualitative methodologies: the majority of qualitative research in SAJBM used interviews, SAJEMS drew case study analysis articles and MD attracted articles that preferred observation and content analysis.

When looking at South African management research over the past fifteen years, it has been dominated by management, financial management, economics and marketing research. More quantitative studies than qualitative research was published, but an increase in the use of qualitative methodologies was observed over the past five years. This might be an indication that authors once again realise the importance of theory building in business management research. Overall, however, the amount of formal theory research has seen a drastic decline in the past fifteen years. This begs the question of whether there is enough theory development in South African management literature (Yadav, 2010).
The number of collaborations between both national and international researchers has also increased over the past fifteen years. There has been a trend internationally towards research collaborations (Coudounaris et al., 2009). One of the most important developments in the post-Apartheid South African academic arena was the opportunity for all South African researchers to collaborate with international scholars. However, South African management research lags behind in both inter-institution and international research collaborations when compared to international journals.

South Africa, like many developing countries, has experienced the so-called brain drain with a migration of talent over the past two decades. Forest and Altbach (2007) state that many academics now keep close contact with their countries of origin maintaining scientific and academic relationships with colleagues and institutions at home. This would imply that the international collaboration figure is even smaller than observed as many of the international authors may be expatriates. Determining the number of international authors that publish in South African journals like SAJBM, SAJEMS and MD that are actually expatriates would be an interesting topic for future research. Noting this, an increase in the number of collaborations between South African and international researchers was observed, most notably other African researchers. This trend needs to continue in future.

\section{References}

Basson, M.J. \& Rothmann, S. 2002. 'Sense of coherence, coping and burnout of pharmacists', South African Journal of Economic and Management Sciences, 5(1):35-62.

Chandy, P.R. \& Williams, T.G.E. 1994. 'The impact of journals and authors on international business research: A citational analysis of JIBS articles', Journal of International Business Studies, 25(4):715-728.

Coudounaris, D., Kvasova, O., Leonidou, L.C., Pitt, L.F. \& Nel, D. 2009. 'Fifteen good years: An analysis of publications in Management International Review', Management International Review, 49(5):671-684.

DuBois, F.L. \& Reeb, D. 2000. 'Ranking the international business journals', Journal of International Business Studies, 31(4):689-704.

Ellis, S.M. \& Steyn, H.S. 2003. 'Practical significance (effect sizes) versus or in combination with statistical significance (p-values): research note', Management Dynamics, 12(4):51-53.

Forest, J.F. \& Altbach, P.G. 2007. International handbook of higher education. Netherlands: Springer.

Gray, B., Matear, S., Boshoff, C. \& Matheson, P. 1998. 'Developing a better measure of market orientation', European Journal of Marketing, 32(9/10):884-903.

Harzing, A. 2010. 'Google Scholar - a new data source for citation analysis'. [online]URL: 
http://www.harzing.com/pop_gs htm. Accessed 22/12/2010.

Harzing, A. \& Van der Wal, R. 2008. 'A Google Scholar HIndex for journals: An alternative metric to measure journal impact in economics \& business', The Journal of the American Society for Information Science and Technology, 60(1):41-46.

Holsapple, C.W., Johnson, L.E., Manakyan, H. \& Tanner, J. 1993. 'A citation analysis of business computing research journals', Information and Management, 25: 231-244.

Inkpen, A.C. \& Beamish, P.W. 1994. 'An analysis of twenty-five years of research in the Journal of International Business Studies', Journal of International Business Studies, 25(4):703-713.

Morrison, A.J. \& Inkpen, A.C. 1991. 'An analysis of significant contributions to the international business literature', Journal of International Business Studies, 22(1):143-153.

Phelan, S.E., Ferreira, M. \& Salvador, R. 2002. 'The first twenty years of the Strategic Management Journal', Strategic Management Journal, 23:1161-1168.

Van der Post, W.Z., De Coning, T.J. \& Smit, E.vd M. 1997. 'An instrument to measure organizational culture', South African Journal of Business Management, 28(4):147-169.

Yadav, M.S. 2010. 'The decline of conceptual articles and implications for knowledge development', Journal of Marketing, 74(Jan):1-19. 